\title{
CONSUMER EXPERIENCE AND THE ROLE OF PROMOTION ON THE MOBILE DEVICE MARKET
}

\author{
Mihalj BAKATOR ${ }^{1}$, Slađana BORIĆ \\ ${ }^{1}$ Republic of Serbia \\ E-mail: mihaljbakator@gmail.com \\ ${ }^{2}$ Republic of Serbia
}

UDC: 339.138:366.1

Original Scientific Paper

Paper received: 27.03.2017.; Paper accepted: 05.05.2017.

\begin{abstract}
In this study, the influence of promotion and product quality on customers' satisfaction was analyzed. The research was conducted via a survey. The goal of the paper was to define and analyze the correlation between variables such as advertising, product quality, brand loyalty and customer satisfaction. The data was statistically processed with a t-test in order to present the data as statistically significantly different. The t-test included the Pearson Correlation, which in all four auxiliary hypotheses was positive. The research provided an insight and strengthened the theory of advertising influence on consumer behavior as well as the concept of brand loyalty and product quality. Further results are presented in the paper.
\end{abstract}

Keywords: Promotion, Customer satisfaction, Influence, Brand, Mobile phone.

\section{INTRODUCTION}

Product branding has emerged as a crucial factor for business excellence. Strong brands ensure the survival of companies on turbulent markets, (Keller \& Lehmann, 2006). Furthermore, companies are aware of the important role of brand. Strategic planning and long-term brand development increase the frequency of sales and overall business performance, (Kotler \& Keller, 2016). Defined in a most simple way, brands serve customers on the market, making it easier to decide which product to buy and to recognize a product on the market from other similar products, (Keller \& Lehmann, 2006).

Brands are a form of equity. Often, companies have more capital in brand equity compared to financial resources. In addition, companies put a lot of effort in brand loyalty research. Their goal is to define which aspects of the brand's image is creating a connection with the customers, (Cleopatra, 2015). The same research defined that passion among customers towards a brand is the main component which shows that people will pay more for a specific brand. The phenomenon where consumers can relate to a brand is called "brand relationship". Furthermore, it can be addressed as consumer-brand relationship, too (Smit, Bronner, \& Tolboom, 2007). Before, advertisers were focused on new customers and generating more leads. However, this changed when companies realized that creating strong relationships with customers is very valuable and strategically makes more sense on the long-run, (Smit, Bronner, \& Tolboom, 2007).

Customer satisfaction is an important factor for customer loyalty development. However, customer loyalty and customer satisfaction are not always positively correlated with financial success, (Williams \& Nauman, 2011). This can happen due to various factors. The product type, value and market segment can influence the re-purchase decision of consumers.

Product quality is often presented as an imperative for financial success and good business performance on the market. The main goal of quality is to satisfy the needs and expectations of consumers. Through this satisfaction, customers become "returning customers" or "loyal customers" (Kuo, Wu, \& Deng, 2009). Companies are evaluating customer satisfaction with the goal 
to modify and improve products in order to achieve higher satisfaction levels, (Kotler \& Keller, 2016). Technology is one the most dynamic factors of development, (Đorđević, Ćoćkalo, \& Bogetić, 2016). New technologies create new opportunities and represent threats to established products which are based on outdated technology.

Promotion and promotional strategies have evolved according to the company's strategic goals, (Kotler \& Keller, 2016). Furthermore, promotional activities focus on strengthening the brands and influencing consumers. In addition, companies are constantly engaging into aggressive advertising campaigns with the goal to stabilize their position on the market, (Liao, Shen, \& Chu, 2009). Promotion is one the main processes of communication with consumers. The goal of promotion is to increase profits or market share (Đorđević \& Ćoćkalo, 2010). Nonetheless, marketing strategies focus on promotional activities which support new products and new product launches. Promotional activities can determine the level of diffusion of a new product on the market (Delre, Jager, Bijmolt, \& Janssen, 2007).

In this paper the role of promotion in brand development on the mobile device market is analyzed. The research was conducted on a sample of $782(\mathrm{~N}=782)$ mobile phone users from cities and villages in Serbia. The data was collected via a survey. The questions included dimensions of brand, promotion, perceived quality and consumer satisfaction. The paper has three main sections. The first section is a theoretical approach which includes brand and branding strategies, customer satisfaction, product quality and promotional strategies. Second, the research methodology is addressed. Third, the research results are presented. Furthermore, the results are analyzed and conclusions are drawn.

\section{THEORETICAL APPROACH}

\section{Brand and branding strategies}

Brands "help" customers to decide whether to buy a specific product or choose another. Brands help consumers to decide and differentiate products on a market, (Kotler \& Keller, 2016). Furthermore, brands represent an image of the company which integrates elements such as quality, corporate image and accumulated customers' experience. This means that brands are the result of customer oriented product development and they address customer needs through innovation and product modification, (Pedeliento, Andreini, Bergamaschi, \& Salo, 2016). Companies are oriented towards a strong competitive position on the market. This goal can be achieved with a strong brand. Strong brand development includes systematic and structured management processes, (Đorđević \& Ćoćkalo, 2010). In addition, companies are eager to develop long-term branding strategies. Brand management is focused on brand positioning and brand development on a specific market. The more developed the brand, the greater the chance for success and survival on the market, (Sanjay \& Keller, 2012). Additionally, products which are sold under a strong brand are more likely to bring great financial success.

Brand management is realized as an integrated part of a brand management system. These systems are projected and defined in a way that they'll bring adequate results and achieve good business performance (Tischer \& Hildebrandt, 2012). Furthermore, brand management systems are focused on long-term planning of brand development. Companies often create, develop or control more than one product brand. This way, if one brand fails on a market segment, the other one can compensate and still achieve moderate business performance. The main factor is the dynamicity of markets. Often, dynamic markets require flexible marketing strategies as well as flexible branding strategies from companies, (Kotler \& Keller, 2016).

When it comes to brand management and branding strategies, the main components which need to be controlled are continuous communication with customers, managing the expectations of shareholders, differentiating expectations of customers from innovation and always keeping promises to customers, (Kotler \& Keller, 2016). Branding strategies are important and it is necessary to implement and use the adequate strategy for a specific product. Some of the branding strategies are, (Kotler \& Keller, 2016):

- Brand name recognition strategy - companies use their own company name which extends to its products;

- Individual branding strategy - the company has products which are distributed under a different brand or name compared to the company that produces it; 
- Style branding strategy - companies use a certain lifestyle or activity which is used to strengthen the brand's image;

- No label branding strategy - companies use this strategy when they sell minimalistic, generic and simply designed products;

- Extending brand strategy - companies use their brand name to similar products from a wide product assortment;

- Private labeling strategy - this strategy is used by companies who want to compete with larger retailers;

- Crowd sourcing branding strategy - in this case potential customers create or are involved in with brand creation.

Companies have to be prepared for changes on the market. Brands play an important role in almost every business model. Small companies can "get away" with underdeveloped brands, but for good business performance, it is necessary to develop strong brands, (Kotler \& Armstrong, 2013). Companies use various channels of distribution in order to send and deliver products, services or messages. The diversity of distribution channels is important for higher profits. In addition, brand development is a process that takes place in the distribution channels, specifically, on the customer-product-company relation (Đorđević \& Ćoćkalo, 2010). It is necessary to take into consideration external factors that influence and affect brand development and brand loyalty. Furthermore, factors such as distribution, financial resources, human resources and intellectual capital need to be addressed, (Tischer \& Hildebrandt, 2012).

\section{Customer satisfaction and product quality}

Customers buy products and services with the goal to satisfy their own needs and wishes. Companies develop products and services with the goal to satisfy customers, (Kotler \& Armstrong, 2013). Customer satisfaction is achieved with adequate product quality and functionality. There is a difference between product quality and perceived product quality. The quality that customers experience is defined as "perceived quality". Companies have to adapt their products to achieve the desired perceived quality of its products, (Percy, 2014). Product quality can be defined as an integrated whole of attributes, design, functionality and the level of how it satisfies customer needs, (Đorđević \& Ćoćkalo, 2007).
Companies synchronize the objective product quality with the perceived product quality in order to make adequate modifications and innovations to satisfy customers. Customers are submissive to buy products under a brand which differentiates from other product brands. This behavior is characteristic for consumer goods, (Kotler \& Armstrong, 2013). A customer buys, for example, cookies under one brand and the next time he or she buys cookies from another brand simply because he or she wants to try something new or different. That is why it is important to develop unique consumer brands that will "stand-out" from identical, competitor brands, (Truong, Klink, Simmons, Grinstein, \& Palmer, 2017).

Consumers are influenced by perceived value and service quality. Furthermore, the result of these two factors on customer satisfaction further affects corporation image and future behavioral intentions (Hu, Kandampully, \& Juwaheer, 2009). Service quality includes pre-purchase and post-purchase services as well as the main act of providing a service. Perceived value is the quality of a product or service from the subjective perspective of the customer. Perceived quality and actual, objective quality of a product or service can be very different. In order, to synchronize the two "types" of quality companies tend to influence customers through various forms of promotional activities, (Jain \& Haley, 2009).

The research of the relationship between satisfaction and loyalty has shown that customer satisfaction affects short-term loyalty more than long-term loyalty, (Fraering \& Minor, 2013). Furthermore, the relationship with a company in terms of re-purchasing positively affects customer loyalty. In addition, through customer loyalty the company gains insights for further brand development. Brand development strives towards customer satisfaction, thus creating a "beyond loyalty" concept that is based on fortitude of consumers and a sense of virtual community, (Fraering \& Minor, 2013).

Furthermore, it is necessary for big enterprises to address the "consumer experience management" concept, where the company and all its actions on the market are controlled, measured and managed widely through the feedback of customers (Hamburg, Jožić, \& Kuehnl, 2015). Markets are in a "whirlpool" of constant changes, and companies must adjust their branding strategies in order to 
survive and establish a competitive market position (Đorđević \& Ćoćkalo, 2007).

Regarding the above presented information about consumer satisfaction, product quality and brand loyalty, it can be assumed that through good product quality that satisfies the needs and expectations of consumers, higher levels of consumer satisfaction can be created, thus inducing and developing brand loyalty.

\section{Promotional strategies}

Modern marketing strategies include product development and more important, they include effective communication with customers. The five major promotional tools are, (Kotler \& Armstrong, 2013):

- corporate propaganda - includes paid nonpersonal presentation and promotion of ideas, products and services;

- personal selling - refers to communication between a salesman and customer with the goal to create a "bond" and relationship with the customer;

- sales improvement - includes short-term "boosts" which encourage the number of product or service sales;

- public relations - is defined as building good relationships with various members of the public and companies with the goal to create a strong and positive corporate image;

- direct marketing - is a relationship building concept with carefully chosen customers with the goal to strengthen customer-company relationships and develop brand loyalty.

Companies invest significant financial and human resources with the goal to develop a strong brand. Furthermore, promotional activities build and develop a positive corporate image (SantosVijande, Río-Lanza, Suárez-Álvarez, \& DíazMartín, 2013). One of the issues of promotional activities is the concept of "perceived information homogeneity". Basically, marketing strategists can clearly define the source of information. However, consumers often don't differentiate the source of promotional messages, and perceive all messages as homogenous entity while the source is irrelevant, (Kotler \& Armstrong, 2013).

Due to the concept of "perceived information homogeneity", there is a need for integrated marketing communications. This type of communication ensures a contingency of messages and avoids confusion among the consumers. Integrated marketing communication includes focused public and market segments and tend to manage, control and influence consumer behavior towards the company and brand, (Kotler \& Armstrong, 2013). It is necessary to strategically plan and target market segments, especially when the market is unstable and constantly endures changes, (Kotler \& Caslione, 2009).

Promotional activities include knowledge management as well. In addition, marketing experts tend to accumulate knowledge and intellectual capital from the company in order to define future "bulletproof" strategies for a specific market. Marketing and knowledge management are important for good business performance (Đorđević, Ćoćkalo, \& Đurin, 2011). It is necessary for companies to acknowledge their weak points in order to sustain itself on "sliding grounds" when the market is unstable. This can be achieved with adequate promotional activities which are well planned and balanced.

In the next section the methodology and hypothesis will be defined. Furthermore, the results from the survey research will be presented. Further, conclusions are drawn. The above and previously mentioned facts addressing brand, product quality and promotion are the "base" of this research and the hypothesis is created accordingly to these facts.

\section{METHODOLOGY AND HYPOTHESES}

The subjects of this research are mobile phone users. Furthermore, customer satisfaction, brand loyalty and promotion are researched through a survey. In addition, the role of promotion in brand development is analyzed. The goal of the research is to define the role of promotion in developing strong brands on the smart phone market. This is achieved through surveying mobile device users.

The research is based on tasks such as defining the main and alternate hypothesis, theoretical research, surveying, statistical data processing and hypothesis testing.

The basis of the research is the main, alternate and auxiliary hypotheses:

$H_{0}$ : Increasing the intensity of promotional activities, increases customer satisfaction.

$H_{a}$ : Increasing promotional activities do not affect customer satisfaction. 
$H_{1}$ : Increasing the intensity of advertisement increases the perceived quality of the mobile devices.

$\mathrm{H}_{2}$ : High intensity advertisement increases the brand's popularity.

$H_{3}$ : The stronger the brand of the product, the better the perceived quality of the mobile device.

$H_{4}$ : The better the quality of the product, the higher the customer satisfaction.

The methods used in this study are evidencing and denial (includes methods such as generalization and concretization, analysis and synthesis, abstraction and specialization). All the data are collected via a survey. The survey included a hundred (100) questions and the respondents had to give answers on a Likert scale where 1 means "I totally disagree" and 7 "I totally agree".

The first group of questions in the survey included factors related to using mobile phones. The questions were collected from other similar research papers (Ragu-Nathan, Tarafdar, RaguNathan, \& Tu, 2008; Lee, Chang, Lin, \& Cheng, 2014). The second group of questions included the questions about customer satisfaction, (Mohd Suki, 2013). The third group of questions included user experience (Kim, Fowler, Shunk, \& Pfund, 2012; Mishra, Dash, \& Cyr, 2014; Wilska, 2003; Sweeney \& Soutar, 2001; Netemeyer et al., 2004), and the fourth group of questions included brand and product quality as well as promotion on the mobile device market (Zhang \& Luo, 2016; Chen $\&$ Ann, 2016). In the next section of this paper, the research results will be presented.

\section{RESEARCH RESULTS}

\section{Promotion and product quality}

Analysis of promotional activities and product quality is based on the $\mathrm{H}_{1}$ auxiliary hypothesis $H_{1}$ : Increasing the intensity of advertisement, increases the perceived quality of the mobile devices. The collected data is processed and analyzed with a ttest. The significance level for every auxiliary hypothesis is set to alpha $=0.05$. The results are given in table 1. Furthermore, a correlation chart is shown on Figure 1.

The $\mathrm{t}$-test shows that there is a significant statistical difference between promotion and product quality. If there were none, it would mean that increasing or decreasing advertising intensity wouldn't affect the perceived product quality. The
Pearson Correlation shows that there is a strong positive correlation between the two variables. However, this doesn't necessary mean causality, but surely it fits to the theoretical research. Therefore, the first auxiliary hypothesis $\mathrm{H}_{1}$ is considered true. Figure 1 shows the data in a simple graphical manner.

Table 1: T-test for promotional activities and product quality

\begin{tabular}{|l|c|c|}
\hline & $\begin{array}{c}\text { Advertising } \\
\text { intensity }\end{array}$ & $\begin{array}{c}\text { Product } \\
\text { quality }\end{array}$ \\
\hline Mean & 4.854 & 5.707 \\
\hline Variance & 0.745 & 1.249 \\
\hline Observations & 782.000 & 782.000 \\
\hline Pearson Correlation & 0.435 & \\
\hline $\begin{array}{l}\text { Hypothesized Mean } \\
\text { Difference }\end{array}$ & 0.000 & \\
\hline df & 781.000 & \\
\hline t Stat & -22.203 & \\
\hline $\mathbf{P}(\mathbf{T}<=t)$ one-tail & 0.000 & \\
\hline $\mathbf{t}$ Critical one-tail & 1.647 & \\
\hline $\mathbf{P}(\mathbf{T}<=$ t) two-tail & 0.000 & \\
\hline $\mathbf{t}$ Critical two-tail & 1.963 & \\
\hline
\end{tabular}

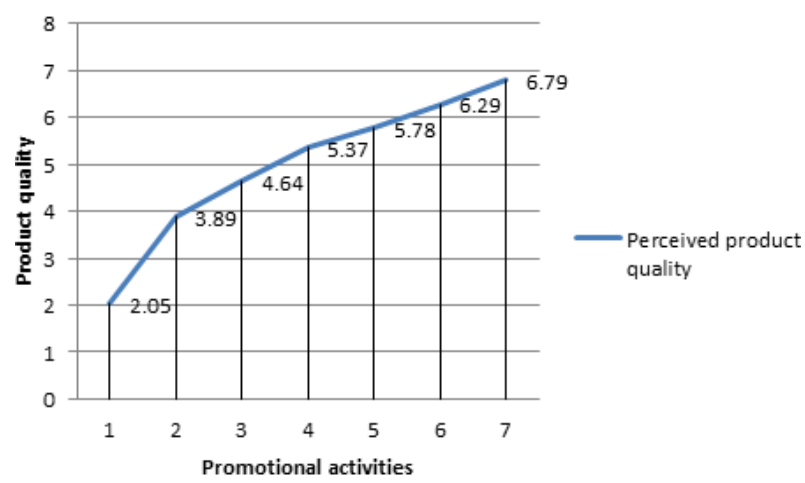

Figure 1: Correlation of promotional activities and product quality

\section{Promotion and brand loyalty}

Analysis of promotional activities and brand loyalty is based on the $\mathrm{H}_{2}$ auxiliary hypothesis $\mathrm{H}_{2}$ : High intensity advertisement increases the brand's popularity. The t-test analysis results are given in table 2. In Figure two the correlation of promotional activities and brand loyalty is shown.

The t-test has given results that clearly show that there is a significant statistical difference between promotional activities and brand loyalty. This is expected, and the Pearson Correlation shows a strong positive correlation between the two variables. Even though, causality is not clearly defined, the theoretical approach and other 
research suggest that indeed high intensity advertising increases brand loyalty. Based on that, the second auxiliary hypothesis $\mathrm{H}_{2}$ is taken as true. Figure 2 shows that brand loyalty is increasing as promotional activities increase as well.

Table 2: T-test for promotional activities and brand loyalty

\begin{tabular}{|l|c|c|}
\hline & $\begin{array}{c}\text { Promotional } \\
\text { activities }\end{array}$ & $\begin{array}{c}\text { Brand } \\
\text { loyalty }\end{array}$ \\
\hline Mean & 4.854 & 4.682 \\
\hline Variance & 0.745 & 2.242 \\
\hline Observations & 782.000 & 782.000 \\
\hline Pearson Correlation & 0.400 & \\
\hline $\begin{array}{l}\text { Hypothesized Mean } \\
\text { Difference }\end{array}$ & 0.000 & \\
\hline df & 781.000 & \\
\hline $\mathbf{t ~ S t a t}$ & 3.448 & \\
\hline $\mathbf{P}(\mathbf{T}<=t)$ one-tail & 0.000 & \\
\hline $\mathbf{t}$ Critical one-tail & 1.647 & \\
\hline $\mathbf{P}(\mathbf{T}<=t)$ two-tail & 0.001 & \\
\hline $\mathbf{t}$ Critical two-tail & 1.963 & \\
\hline
\end{tabular}

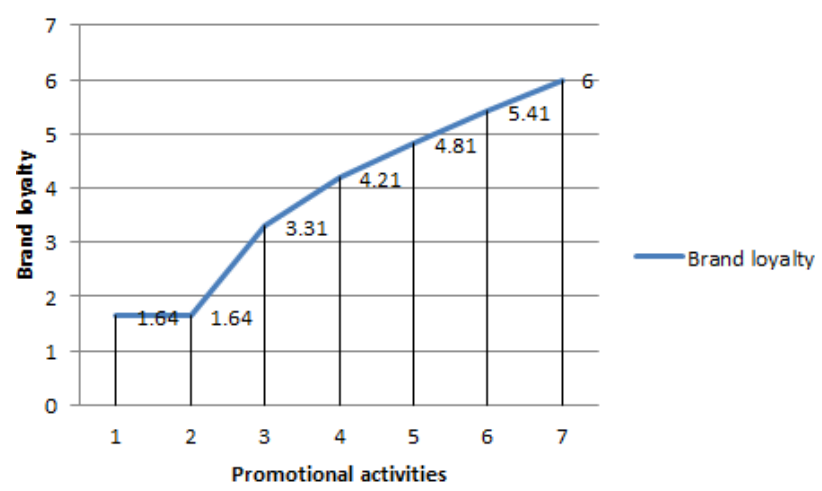

Figure 2: Correlation of promotional activities and brand loyalty

\section{Brand loyalty and product quality}

Analysis of brand loyalty and product quality is based on the $\mathrm{H}_{3}$ auxiliary hypothesis $H_{3}$ : The stronger the brand of the product, the better the perceived quality of the mobile devices. The t-test analysis results are given in table 3. In Figure 3 the correlation between brand loyalty and product quality is shown.

The t-test analysis shows that there is a significant difference between the two variables. The Pearson Correlation shows a strong positive correlation. Figure 3 presents the correlation, and it's strongly positive. Furthermore, taken into consideration other studies, the auxiliary hypothesis $\mathrm{H}_{3}$ is considered as true.
Table 3: T-test for brand loyalty and product

\begin{tabular}{|l|c|c|}
\hline \multicolumn{3}{|c}{ quality } \\
\hline & $\begin{array}{c}\text { Brand } \\
\text { loyalty }\end{array}$ & $\begin{array}{c}\text { Product } \\
\text { quality }\end{array}$ \\
\hline Mean & 4.682 & 5.707 \\
\hline Variance & 2.242 & 1.249 \\
\hline Observations & 782.000 & 782.000 \\
\hline Pearson Correlation & 0.666 & \\
\hline $\begin{array}{l}\text { Hypothesized Mean } \\
\text { Difference }\end{array}$ & 0.000 & \\
\hline df & 781.000 & \\
\hline $\mathbf{t}$ Stat & -25.523 & \\
\hline $\mathbf{P}(\mathbf{T}<=$ t) one-tail & 0.000 & \\
\hline $\mathbf{t}$ Critical one-tail & 1.647 & \\
\hline $\mathbf{P}(\mathbf{T}<=t)$ two-tail & 0.000 & \\
\hline $\mathbf{t}$ Critical two-tail & 1.963 & \\
\hline
\end{tabular}

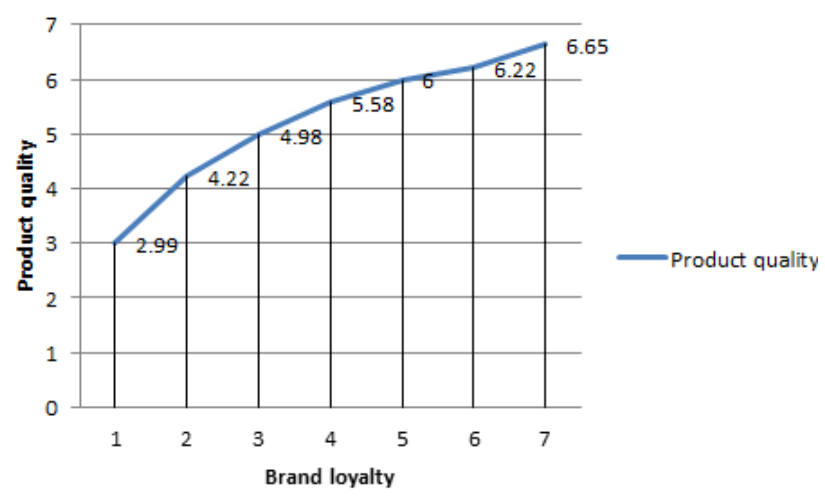

Figure 3: Correlation of product quality and brand loyalty

\section{Product quality and customer satisfaction}

Analysis of product quality and customer satisfaction is based on the $\mathrm{H}_{4}$ auxiliary hypothesis $H_{4}$ : The better the quality of the product, the higher the customer satisfaction. The collected data are processed and analyzed with a t-test. The results are shown in table 4. In Figure 4 the correlation of product quality and customer satisfaction is shown.

The t-test gave the expected results. There is a significant statistical difference between the two variables and the Pearson Correlation shows strong positive correlation. Figure 4 presents the correlation of product quality and customer satisfaction. The chart shows a strong positive correlation. Furthermore, this doesn't prove causality. However, other studies and theoretical analysis give a strong base for conclusions and the auxiliary hypothesis $\mathrm{H}_{4}$ can be considered as true. 
Table 4: T-test for product quality and customer satisfaction

\begin{tabular}{|l|c|c|}
\hline & $\begin{array}{c}\text { Product } \\
\text { quality }\end{array}$ & $\begin{array}{c}\text { Customer } \\
\text { satisfaction }\end{array}$ \\
\hline Mean & 5.707 & 5.095 \\
\hline Variance & 1.249 & 2.304 \\
\hline Observations & 782.000 & 782.000 \\
\hline Pearson Correlation & 0.459 & \\
\hline $\begin{array}{l}\text { Hypothesized Mean } \\
\text { Difference }\end{array}$ & 0.000 & \\
\hline df & 781.000 & \\
\hline $\mathbf{t}$ Stat & 12.127 & \\
\hline $\mathbf{P}(\mathbf{T}<=t)$ one-tail & 0.000 & \\
\hline $\mathbf{t}$ Critical one-tail & 1.647 & \\
\hline $\mathbf{P}(\mathbf{T}<=t)$ two-tail & 0.000 & \\
\hline $\mathbf{t}$ Critical two-tail & 1.963 & \\
\hline
\end{tabular}

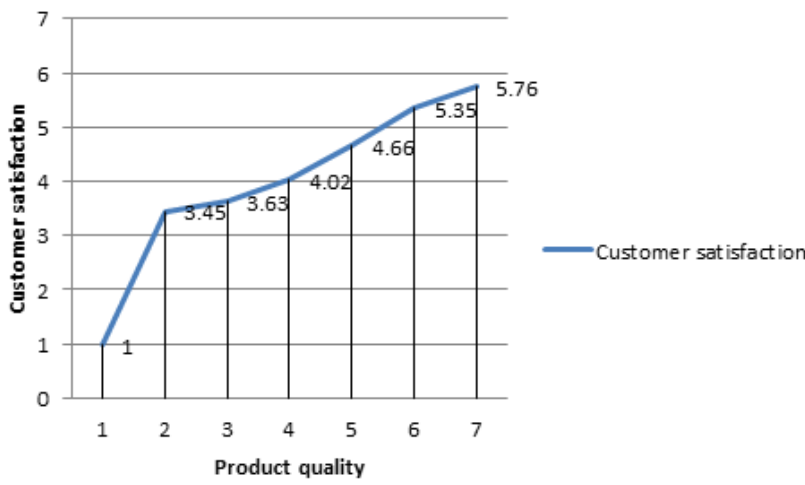

Figure 4: Correlation of product quality and customer satisfaction

As a result, the main hypothesis $H_{0}$ : Increasing the intensity of promotional activities, increases customer satisfaction can't be rejected while the alternate hypothesis $H_{a}$ : Increasing promotional activities, doesn't affect customer satisfaction is rejected.

\section{CONCLUSION}

The t-test analysis and the Pearson Correlation analysis showed positive correlation between the analyzed variables. This doesn't strictly mean causality but other studies have shown that there is a connection between product quality and customer satisfaction. More precisely, it is concluded in the previous research that product quality increases overall customer satisfaction, (Dong-Hee, 2014). Furthermore, promotional activities such as loyalty programs increase the perceived value and product quality among consumers, (Stathopoulou \& Balabanis, 2016). It is necessary to take into consideration other factors that influence consumers. However, there is no doubt that promotional activities and brand loyalty affect consumer satisfaction. The research conducted in this paper focused on addressing the influence of advertising on consumers on the mobile devices market.

Further research is proposed in the area of brand loyalty and promotional activities. Companies have to focus on new distribution channels and communication channels. This study shows that brand loyalty and advertising indeed have an impact on the market. There is a statistically significant difference between the answers of various variables. Furthermore, the Pearson Correlation for every pair of variables is strong and positive. In addition, other studies conducted on this matter, also got similar results. As reported before, in this study, the main hypothesis can't be rejected. The data collected give a solid base for setting the main hypothesis.

It is recommended to collect more data on mobile phone brands and include network providers as well. This will increase the accuracy of the research, especially the data which show the strength and influence of brands. Furthermore, other factors should be considered such as environmental and social influences. When these factors are defined and included, a more objective "picture" can be obtained of how promotion and customer satisfaction are correlated and how they influence each other.

\section{REFERENCES}

Chen, C. M., \& Ann, B. Y. (2016). Efficiencies vs. importance-performance analysis for the leading smartphone brands of Apple, Samsung and HTC Total Quality Management \& Business Excellence, 27(3-4), 227-249.

Cleopatra, V. (2015). Brand evaluation, satisfaction and trust as predictors of brand loyalty: the mediatormoderator effect of brand relationships. Journal of Consumer Marketing, 32(6), 405-421.

Delre, S. A., Jager, W., Bijmolt, T. H., \& Janssen, M. A. (2007). Targeting and timing promotional activities: An agent-based model for the takeoff of new products. Journal of business research, 60(8), 826835 .

Dong-Hee, S. (2014). Measuring the quality of smartphones: development of a customer satisfaction index for smart services. International Journal of Mobile Communications, 12(4), 311-327.

Đorđević, D., Ćoćkalo, D. (2010). Osnove marketinga. Zrenjanin: Tehnički fakultet "Mihajlo Pupin" 
Đorđević, D., \& Ćoćkalo, D. (2007). Upravljanje kvalitetom.Zrenjanin: Tehnički fakultet "Mihajlo Pupin"

Đorđević, D., Ćoćkalo, D., \& Bogetić, S. (2016). The analysis of marketing concept implementation in domestic enterprises. Journal of Engineering Management and Competitiveness (JEMC), 6(2), 120-128.

Đorđević, D., Ćoćkalo, D., \& Đurin, S. (2011). Serbian enterprises and global competition challenges. Journal of Engineering Management and Competitiveness (JEMC), 1(1/2), 27-31.

Fraering, M., \& S. Minor, M. (2013). Beyond loyalty: customer satisfaction, loyalty, and fortitude. Journal of Services Marketing, 27(4), 334-344.

Hamburg, C., Jožić, D., \& Kuehnl, C. (2015). Customer experience management: toward implementing an evolving marketing concept. Journal of the Academy of Marketing Science, 17(4), 1-25.

Hu, H. H., Kandampully, J., \& Juwaheer, T. D. (2009). Relationships and impacts of service quality, perceived value, customer satisfaction, and image: an empirical study. The Service Industries Journal, 29(2), 111-125.

Jain, S. C., \& Haley, G. T. (2009). Marketing planning and strategy. Cincinnati South-Western Publishing Company 1985.

Keller, K. L., \& Lehmann, D. R. (2006). Brands and Branding: Research Findings and Future Priorities. Marketing Science, 25(6), 740-759.

Kotler, P., \& Armstrong, G. (2013). Principles of marketing 15th global edition. Pearson.

Kotler, P., \& Caslione, J. A. (2009). Chaotics. New York, NY: AMACON.

Kotler, P., \& Keller, L. K. (2016). Marketing management. Englewood Cliffs, NJ: Prentice Hall.

Kim, S. H., Fowler, J. W., Shunk, D. L., \& Pfund, M. E. (2012). Improving the push-pull strategy in a serial supply chain by a hybrid push-pull control with multiple pulling points. International Journal of Production Research, 50(19), 5651-5668.

Kuo, Y. F., Wu, C. M., \& Deng, W. J. (2009). The relationships among service quality, perceived value, customer satisfaction, and post-purchase intention in mobile value-added services. Computers in human behavior, 25(4), 887-896.

Lee, Y. K., Chang, C. T., Lin, Y., \& Cheng, Z. H. (2014). The dark side of smartphone usage: Psychological traits, compulsive behavior and technostress. Computers in Human Behavior, 31(3), 373-383.

Liao, S. L., Shen, Y. C., \& Chu, C. H. (2009). The effects of sales promotion strategy, product appeal and consumer traits on reminder impulse buying behaviour. International Journal of Consumer Studies, 33(3), 274-284.

Mohd Suki, N. (2013). Students' demand for smartphones: Structural relationships of product features, brand name, product price and social influence. Campus-Wide Information Systems, 30(4), 236-248.

Mishra, A., Dash, S. B., \& Cyr, D. (2014). Linking user experience and consumer-based brand equity: the moderating role of consumer expertise and lifestyle. Journal of Product \& Brand Management, 23(4/5), 333-348.

Netemeyer, R.G., Krishnan, B., Pullig, C., Wang, G., Yagci, M., Dean, D., Ricks, J. and Wirth, F. (2004).Developing and validating measures of facets of customer-based brand equity. Journal of Business Research, 57 (2), 209-224.

Ragu-Nathan, T. S., Tarafdar, M., Ragu-Nathan, B. S., \& Tu, Q. (2008). The consequences of technostress for end users in organizations: Conceptual development and empirical validation. Information Systems Research, 19(4), 417-433.

Pedeliento, G., Andreini, D., Bergamaschi, M., \& Salo, J. (2016). Brand and product attachment in an industrial context: The effects on brand loyalty. Industrial Marketing Management, 53, 194-206.

Percy, L. (2014). Strategic integrated marketing communications. Routledge.

Sanjay, S., \& Keller, K. L. (2012). The effects of brand name structure on brand extension evaluations and parent brand dilution. Journal of Marketing Research, 49(3), 373-382.

Santos-Vijande, M. L., del Río-Lanza, A. B., SuárezÁlvarez, L., \& Díaz-Martín, A. M. (2013). The brand management system and service firm competitiveness. Journal of Business Research, 66(2), 148-157.

Smit, E., Bronner, F., \& Tolboom, M. (2007). Brand relationship quality and its value for personal contact. Journal of Business Research, 60(6), 627 633.

Stathopoulou, A., \& Balabanis, G. (2016). The effects of loyalty programs on customer satisfaction, trust, and loyalty toward high- and low-end fashion retailers. Journal of Business Research, 69(12), 5801-5808.

Sweeney, J.C. and Soutar, G.N. (2001). Consumer perceived value: the development of a multiple item scale. Journal of Retailing, 77(2), 203-220.

Truong, Y., Klink, R. R., Simmons, G., Grinstein, A., \& Palmer, M. (2017). Branding strategies for hightechnology products: The effects of consumer and product innovativeness. Journal of Business Research, 70, 85-91.

Tischer, S., \& Hildebrandt, L. (2012). Brand EquityHow is it Affected by Critical Incidents and What Moderates the Effect. Humboldt University, Berlin, Germany.

Williams, P., \& Nauman, E. (2011). Customer satisfaction and business performance: a firm-level analysis. Journal of Services Marketing, 25(1), 2032.

Wilska, T.A. (2003). Mobile phone use as part of young people's consumption styles, Journal of Consumer Policy, 26(4), 441-463. 
Zhang, M., \& Luo, N. (2016). Understanding relationship benefits from harmonious brand community on social media. Internet Research, 26(4), 809-826.

\section{ISKUSTVO POTROŠAČA I ULOGA PROMOCIJE NA TRŽIŠTU MOBILNIH UREĐAJA}

U ovom radu analizirali su se promocija i brend proizvoda kao uticajni faktori na zadovoljstvo potrošača. Istraživanje je sprovedeno putem upitnika. Cilj rada je bio analiza i definisanje korelacije između varijbali kao što su privredna propaganda, kvalitet proizvoda, lojalnost brendu i zadovoljstvo potrošača. Prikupljeni podaci su se statički obradili i urađen je i t-test kako bi se utvrdilo da li postoji statistčki značajna greška. Urađena je i Pirsenova korelacija koja je za sve četiri pomoćne hipoteze bila pozitivna. Istraživanje je pružilo uvid u problematiku i učvrstila je teorijska istraživanja o uticaju privredne propagande na ponašanje potrošača kao i koncepta lojalnosti brendu i kvaliteta proizvoda. Dalji rezultati su prikazani u radu.

Ključne reči: Promocija, Zadovoljstvo potrošača, Uticaj, Brend, Mobilni telefon 